University of Nebraska - Lincoln

DigitalCommons@University of Nebraska - Lincoln

November 2001

\title{
Revision of the genus Holocephalus (Coleoptera: Scarabaeidae: Scarabaeinae: Coprini)
}

Andrew Smith

asmith@unl.edu

François Génier

Canadian Museum of Nature, fgenier@mus-nature.ca

Follow this and additional works at: https://digitalcommons.unl.edu/entomologypapers

Part of the Entomology Commons

Smith, Andrew and Génier, François, "Revision of the genus Holocephalus (Coleoptera: Scarabaeidae: Scarabaeinae: Coprini)" (2001). Papers in Entomology. 14.

https://digitalcommons.unl.edu/entomologypapers/14

This Article is brought to you for free and open access by the Museum, University of Nebraska State at DigitalCommons@University of Nebraska - Lincoln. It has been accepted for inclusion in Papers in Entomology by an authorized administrator of DigitalCommons@University of Nebraska - Lincoln. 


\title{
Revision of the genus Holocephalus (Coleoptera: Scarabaeidae: Scarabaeinae: Coprini)
}

\author{
Andrew BT Smith' \\ Division of Entomology, University of Nebraska State Museum, W436 Nebraska Hall, \\ University of Nebraska, Lincoln, Nebraska, United States 68588-0514 \\ François Génier \\ Canadian Museum of Nature, PO Box 3443, Station D, Ottawa, Ontario. Canada K1P 6P4
}

The Canadian Entomologist 133: 777 - 792 (2001)

\begin{abstract}
The genus Holocephalus Hope is revised and now contains five species: $H$. cristatus (Gillet), H. eridanus (Olivier), H. julieni sp.nov. H. sculptus (Gillet), and H. simoni sp.nov.All taxa are described and illustrated.Akey to species of Holocephalus is included. Lectotypes are designated for $H$. eridanus and $H$. sculptus. Scarabaeus eridanus Olivier is designated as the type species for the generic name Atrichius Gillet (a junior synonym of Holocephalus).

Smith ABT, Génier F. 2001, Révision du genre Holocephalus (Coleoptera : Scara-

baeidae : Scarabaeinae: Coprini). The Canadian Entomologist 133 : 777-792.

Résumé-On révise le genre Holocephalus Hope qui regroupe maintenant cinq es-pèces, soit $H$. cristatus (Gillet), $H$. eridanus (Olivier), $H$. julieni sp.nov., $H$. sculptus (Gillet) et $H$. simoni sp.nov. Outre les descriptions et illustrations pour chaque espèces on propose un tableau de détermination pour les espèces maintenant comprises dans le genre Holocephalus. On désigne des lectypes pour $H$. eridanus et $H$. sculptus. Enfin, on désigne l'espèce Scarabaeus eridanus Olivier comme type du genre Atrichius Gillet (considéré comme synonymec junior du genre Holocephalus).
\end{abstract}

\section{Introduction}

Holocephalus Hope (Coleoptera: Scarabaeidae: Scarabaeinae: Coprini) is a small genus of dung beetles from Paraguay and southern Brazil. All Holocephalus species are large-bodied (2-4 cm long), glossy dark reddish-brown to black, and with mouthparts densely covered with short, stout, reddish-brown setae. The triballevel classification of the subfamily Scarabaeinae is currently unstable and rapidly changing. We consider the genus Holocephalus to be in the tribe Coprini, based on the work and classification scheme of Montreuil (1998).

This paper is a continuation of the taxonomic revision of the New World genera of Coprini by Génier. To maintain compatibility with earlier papers in this series, the format used here conforms to Génier (1996).

Holocephalus shares many character states with the genus Dichotomius Hope. To find the sister group of Holocephalus, many species of Dichotomius were examined. Of all the taxa studied, species belonging to Lüderwaldt's "Dichotomius bitiensis group" seem to share most character states with Holocephalus. Dichotomius bitiensis (Gillet) and Holocephalus species are particularly similar and share the following character states: clypeus oval shaped, lacking distinct median indentation; transverse cephalic process similar in males and females: pronotal configuration similar in both sexes,

${ }^{1}$ Author to whom all correspondence should be addressed (E-mail: asmith@unlserve.unl.edu). 
including presence of longitudinal median sulcus (similar to H. sculptus, which we consider the least-derived species in the genus); and parameres ventrally with heavily sclerotized valves. If this relationship is based on apomorphic characters, it would suggest that Holocephalus evolved recently, because D. bitiensis seems to be a more-derived species within the genus Dichotomius. Other evidence that the genus Holocephalus is a relatively recent group includes the probability that all species of Holocephalus are myrmecophiles, the small number of species in the genus, and the limited distribution. Future study on the phylogeny of this group could indicate that subgeneric placement within Dichotomius is more appropriate.

\section{Taxonomic history}

Holocephalus eridanus (Olivier), the first-described species in the genus, was originally placed in the genus Scarabaeus Linnaeus (Olivier 1789). Hope (1838) subsequently erected the subgenus Holocephalus (of the genus Copris Geoffroy) for $H$. eridanus and several other species, including Dichotomius carolinus (Linnaeus), as well as three names that were not formally made available under the rules of zoological nomenclature: "Copris monachus," CC nasutus" and "C rhinoceros." Hope (1838) designated $H$. eridanus as the type species of Holocephalus. Hope's paper was overlooked by later workers, including Harold $(1869 a, 1869 b)$, who placed $H$. eridanus in the ge nus Pinotus Erichson. Gillet (1907), also unaware of Hope's work, placed H. eridanus in a new genus, Atrichius Gillet, and described two new species in that genus: Atrichius cristatus Gillet and A. sculptus Gillet. Gillet (1911) later realized his error and transferred these three species to the genus Holocephalus. Little research has been done on this genus in the last 90 years. Vaz-de-Mello et al. (1998) reported on the myrmecophilous habits of $H$. eridanus. The life histories of the other species of Holocephalus are unknown, but they are probably also myrmecophiles, as suggested by the same modifications in mouthparts (Figs. 3,4), antenna (Fig. 5), and tarsi (Fig. 6) (see diagnosis of the genus for more details)

\section{Specimens}

A total of 317 specimens from the 18 institutional and private collections listed below were examined for this revision.

BMNH The Natural History Museum, London, United Kingdom (Malcolm Kerley).

CASC California Academy of Sciences, San Francisco, California, United States (Dave Kavanaugh, Roberta Brett).

CMNC Canadian Museum of Nature, Ottawa, Ontario, Canada.

CNCI Canadian National Collection of Insects, Ottawa, Ontario, Canada (Yves Bousquet, Serge Laplante).

DEIC Deutsches Entomologisches Institut, Eberswalde Finow, Germany (Lothar Zerche).

FZVC Fernando Vaz-de-Mello Collection, Viçosa, Minas Gerais, Brazil ISNB Institut Royal des Sciences Naturelles de Belgique, Brussels, Belgium (Marcel

LACM Los Angeles County Museum of Natural History, Los Angeles, California, United States (Brian Brown).

MCSN Museo Civico di Storia Naturale "Giacomo Doria," Genova, Italy (Roberto Poggi)
MNHN Muséum National d'Histoire Naturelle, Paris, France (Yves Cambefort, Olivier Montreuil).

MZSP Museu de Zoologia da Universidade de São Paulo, São Paulo, Brazil (Ubirajara Martins).

NMPC National Museum (Natural History), Prague, Czech Republic (Josef Jelinek).

SMFD Forschungsinstitut und Naturmuseum Senckenberg, Frankfurt-am-Main Germany (Damir Kovac).

SMTD Staatliches Museum für Tierkunde, Dresden, Germany (Dirk Ahrens).

USNM United States National Museum, Washington, DC, United States (Dave Furth, Gloria House).

ZMHB Museum für Naturkunde der Humboldt-Universität zu Berlin, Berlin, Germany (Manfred Uhlig, Hella Wendt).

ZMUC University of Copenhagen, Zoological Museum, København, Denmark (Ole Martin).

ZSMC Zoologische Staatssammlung des Bayerischen Staates, München, Germany (Gerhard Scherer).

\section{Holocephalus Hope, 1838}

Holocephalus Hope 1838: 323. Type species Scarabaeus eridanus Olivier by original designation. Holocephalus was originally described as a subgenus of Copris. Atrichius Gillet 1907: 282. Type species Scarabaeus eridanus Olivier HERE DES-

IGNATED. Placed in synonymy by Gillet (1911).

\section{Diagnosis}

The reduced antennal club (Fig. 5), greatly enlarged (Figs. 3,4) and heavily setose first segment of labial palpus concealing the third and second segments, quadrate basal half of mesotibia and metatibia, and large size (total length $23.0-35.5 \mathrm{~mm}$ ) will separate Holocephalus from all other Scarabaeinae genera in the New World.

\section{Description}

Body robust, wide, dorsally flattened (more convex in $H$. cristatus). Size moderate to large (length $23.0-35.5 \mathrm{~mm}$; width $14.0-22.0 \mathrm{~mm}$ ). Head. Anterior edge oval, without distinct median indentation, marginal bead slightly reflexed, wider medially. Clypeus with strong, transverse, irregular ridges. Clypeofrontal region with strong, transverse tubercle in both sexes. Eyes slightly reduced in size (strongly reduced in $H$. cristatus), always visible from above. Ocular canthus with posterior edge not reaching occipital margin. Anteroventral portion of clypeus with blunt, conical process or transverse bulge. Labium (Fig. 3) transverse, semicircularly emarginate on median third, ventral surface rugose, densely covered with short, stout, reddish-brown setae. Labial palpus (Fig. 4) 3-segmented; first segment oval, large, with vesture similar to labium; second and third segments much smaller, mostly concealed by first segment in ventral view Antenna (Fig 5) 9-segmented; scape slightly flattened; segments $2-3$ as long as wide; segments 4-6 transverse; club 3-segmented, reduced in size. Pronotum. Similar in both sexes; transverse, moderately convex; distinct, transverse bulge on anterior third; with 1 or several rows of coarse punctures along posterior marginal bead. Longitudinal sulcus well-defined, medially extending on most of surface between transverse bulge and posterior pronotal margin. Lateral portions with a single, oval depression. Elytron. Surface with 9 striae; striae 1-7 normally impressed (striae 6-7 sometimes ill-defined basally or for entire length); striae 8-9 fused on basal third, 
separated on apical two-thirds. Strial punctures variable. Intervals nearly flat; surface completely glossy; covered with dense, minute punctures; surface along striae opaque (except in $H$. cristatus and $H$. eridanus). Epipleura lacking aligned row of setose punctures. Legs. Protarsi always present. Anterior spur movable, slightly arcuate. Protibia with 4 teeth, basal teeth small, apical edge oblique. Ventromedian carina complete, sharp, lacking intervening setae. Mesotibiae and metatibiae quadrate in cross section on basal half, strongly expanding towards apex on posterior half, lacking transverse carinae on lateral edge. Mesotibia with 2 uneven spurs at apex. Metatibia with single spur. Mesotarsi and metatarsi long. segments subequal in length, becoming gracile toward apex. Tarsal claws reduced in size. Venter. Proepisternum evenly convex; glossy on most of surface; with coarse, setose punctures anteriorly; lacking transverse carina. Prosternum with posterior edge sinuous. Mesosternum transverse, median portion convex, smooth; lateral portions slightly concave, rugose. Mesometasternal suture broadly arcuate. Metasternum length twice width. Median coxal cavities slightly divergent anteriorly. Abdominal sternites $2-5$ with sutures distinct, feebly indicated medially. Abdominal sternite 6 narrowed medially in male, wide medially in female. Pygidium transverse, with complete marginal bead in both sexes. Male genitalia. Parameres symmetrical, with ventral valves symmetrical, heavily sclerotized. Female genitalia. Spermatheca crescent- to U-shaped, proximal portion flattened, distal portion tubular, rounded apically (not studied in $H$. julieni and $H$. simoni).

\section{Key to the species of adult Holocephalus}

1. Eyes reduced, ventral portion narrow (Fig. 1). Posterior portion of cephalic horn strongly rugosc, with wel defined V-shaped carina. Elytron short, semicircular when viewed laterallys Hind wing brachypterous, not reaching apex of elytron; flightless. Brazil (Mato Grosso), Paragualy .

1. Holocephalus cristatus (Gillet)

I' Eycs normal ventral portion fully developed (Fis 2) Posterior portion of cephalic horn at most ylightly ruase, lacking carina, with porly defined swelling. Elytron longer, dorsally flattened when viewed latcrally. Hind wing fully developed, folded; capable of flight

2. Pronotum anteriorly with tubercle on each side of subrectangular, median protuberance (Fig. 24) Pronotum with coarse punctures of anterior declivity extending beyond outer edge of eyes, punctures present on each side between tubercles and median protuberance. Brazil (Bahia. Espirito Santo, Minas Gerais) . . . . . . . . . . . . . . . 2. Holocephalus sculptus (Gillct)

2'. Pronotum anteriorly lacking tubercle on each side of median protuberance (Figs. 25-27). Pronotum with coarse punctures sct in triangular region of anterior declivity, largely restricted to anteronedian depression

3. Cephalic process with median portion depressed, lateral angles produced into acute. conical tubercles (Fig. 25). Apical portion of cephalic process less than half head width. Pronotum with median protuberance narrow, less than half pronotal width, arcuate in dorsal view. Brazil (Bahia, Espirito Santo, Minas Gerais, Pernambuco, Rio de Janeiro, Rio Grande do Sul, São Paulo) .

3. Holocephalus eridanus (Olivier

3'. Cephalic process with median portion raised or not depressed compared with lateral angles (Figs. 26 27). Apical portion of cephalic process more than half head width. Pronotum with median protuberance wide more than half pronotal width, straight in dorsal view.

4. Elytral striae 1 and 2 shallowly impressed apically, lacking distinct punctures. Paramere with ventral portion not extending beyond lateral edge in dorsal view (Fig. 18). Brazil (Goyas)

4. Holucephalus simoni Smith and Génier sp.nov

4. Elytral striae 1 and 2 deeply impressed apically, with distinct punctures. Paramere with ventral portion extending beyond lateral edge in dorsal view (Fig. 21). Brazil (Minas Gerais, Rio Grande do Sul)

$$
\text { 5. Holocephalus julieni Smith and Génier sp.nov. }
$$
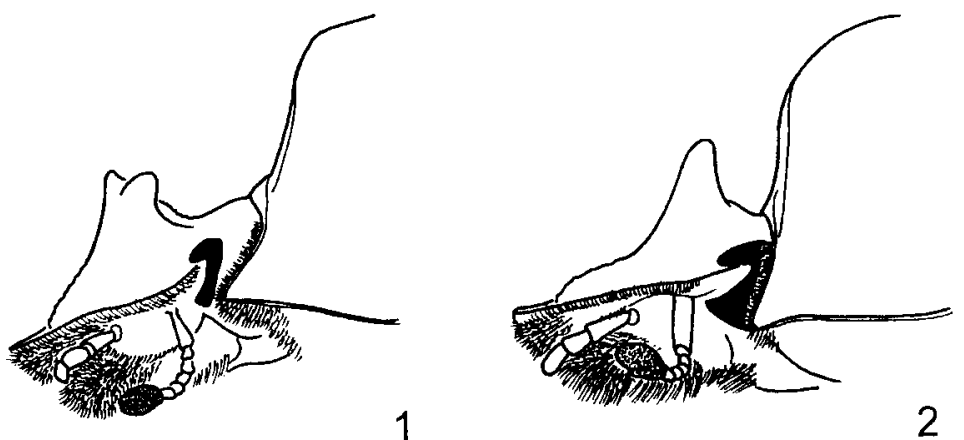

2
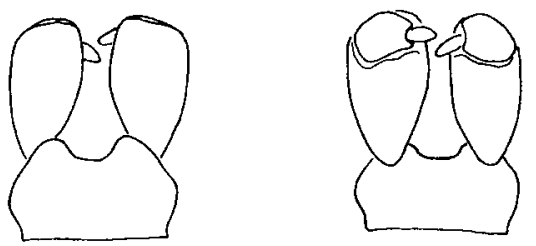

3

4
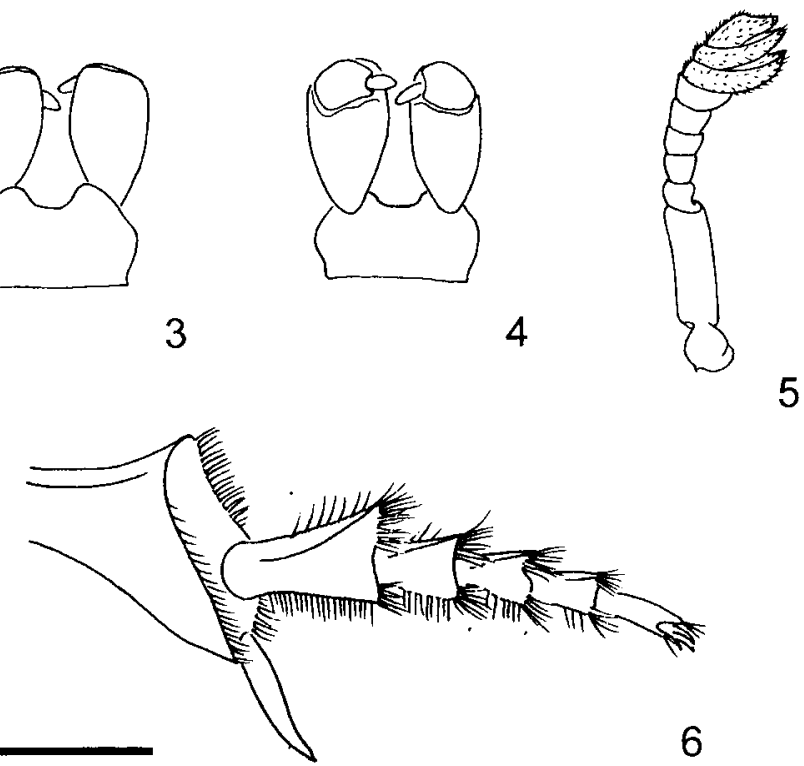

FICURPS 1-6. 1, Holocephalus cristatus head, lateral view; 2, Holocephalus eridanus head, lateral view; 3, Holocephalus species labium, ventral view; 4, Holocephalus species labium, dorsal view; 5 , , Holoce (Figs. 1-2) and $2.0 \mathrm{~mm}$ (Figs. 3-6).

\section{Holocephalus cristatus (Gillet, 1907)}

(Figs. 1, 7-9, 22-23, 28)

Atrichius cristatus Gillet 1907: 284.

Holocephalus cristatus (Gillet): Gillet 1911: 58.

Holocephalus cristatus (Gillet): Blackwelder 1944: 206. 
$7 \times 2$

THECANABIANENTOMOLOGIST

November/December 2001

Volume 133

THE: CANADIANENTGMOLOGIST

783

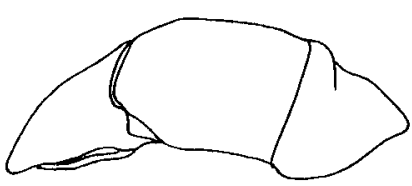

7
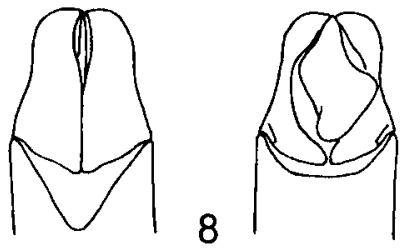

9

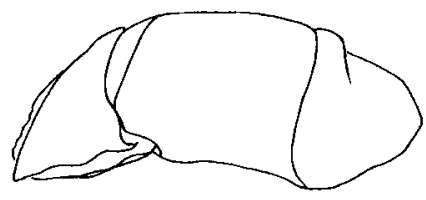

10

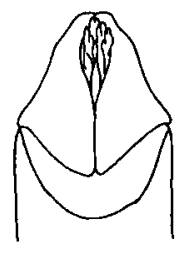

11
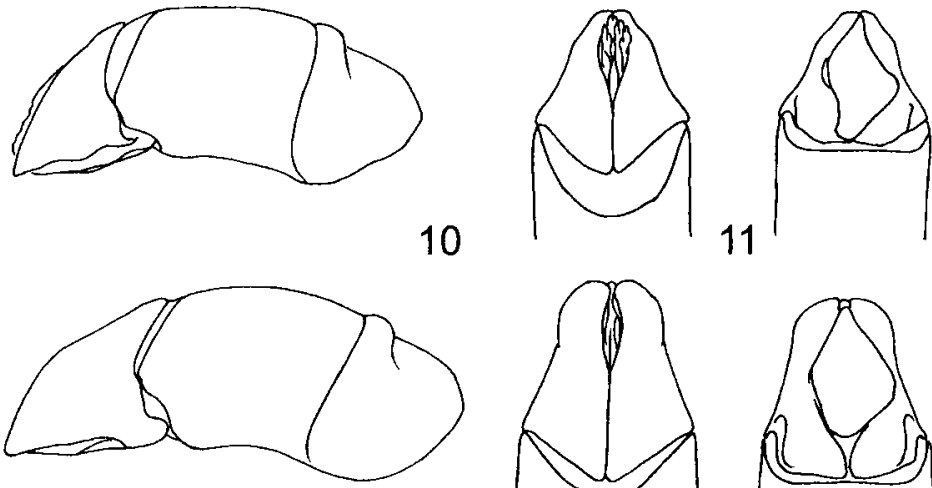

13
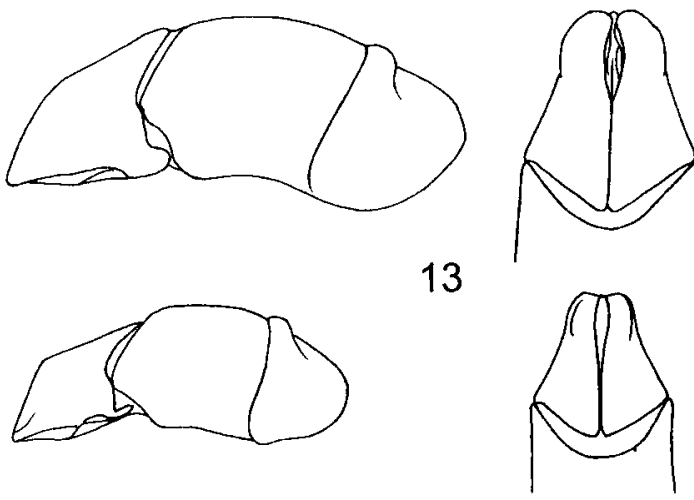

14

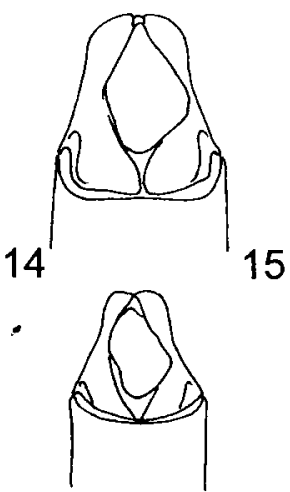

12

16

17

18
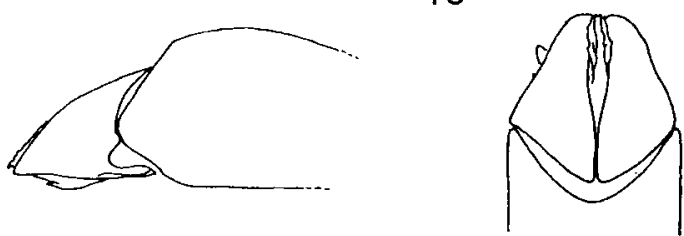

19

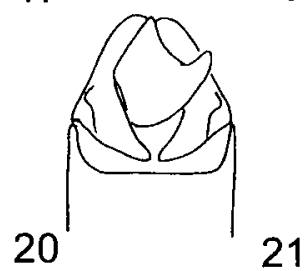

Figures 7-21. 7-9, Parameres and phallobase of Holocephalus cristatus: 7, lateral view; 8, dorsal view; 9, ventral view. 10-12, Parameres and phallobase of Holocephalus sculptus: 10, lateral view; 11, dorsal view; 12, ventral view. 13-15, Parameres and phallobase of Holocephalus eridanus: 13, lateral view; 14, dorsal view; 15, ventral view. 16-18, Parameres and phallobase of Holocephalus simoni: 16, lateral view; 17, dorsal view; 18, ventral view. 19-21, Parameres and phallobase of Holocephalus julieni: 19, lateral view; 20 , dorsal view; 21 , ventral view. Scale bar $=2.0 \mathrm{~mm}$.

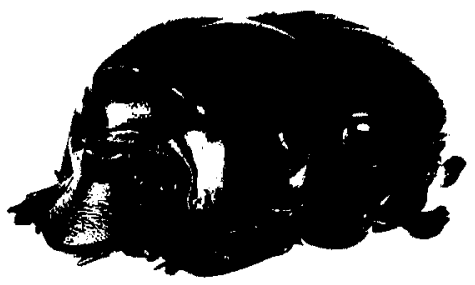

22

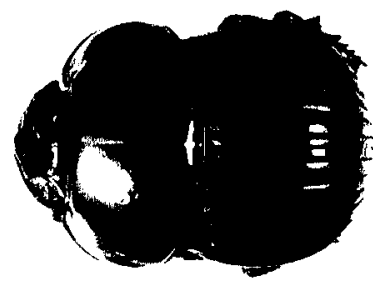

23

24
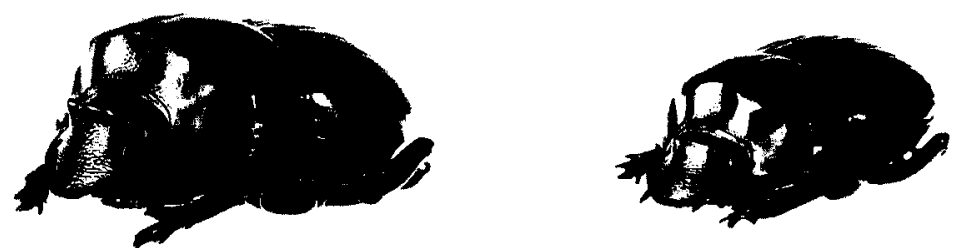

26

27

Figures 22-27. 22-23, Holocephalus cristatus; 24, Holocephalus sculptus; 25, Holocephalus eridanus; 26, Holocephalus simoni; 27, Holocephalus julieni. Scale bar $=10.0 \mathrm{~mm}$.

Material studied

$70^{\circ} 0^{\circ}, 11$ 우 (BMNH, CMNC, ISNB, LACM, MCSN, MZSP, ZMHB).

Holotype: Male (MCSN): "Asuncion Paraguay Balzan 1890" (white with black border, typeface and handwritten) / "Museo Civ Genova" (red, typeface) / "Typus" (red border and letters, typeface) / "Atrichius cristatus n.sp. Gillet" (handwritten) / "Atrichius cristatus Gillet" (handwritten) / "HOLOTYPUS o" Atrichius cristatus Gillet, 1907" (red, typeface and handwritten) / "Atrichius cristatus Gillet $\sigma$ " Holocephalus cristatus Gill." (black border, handwritten). The original description by Gillet (1907) was based on one male specimen, therefore the holotype is fixed by monotypy. Aedeagus extracted. 


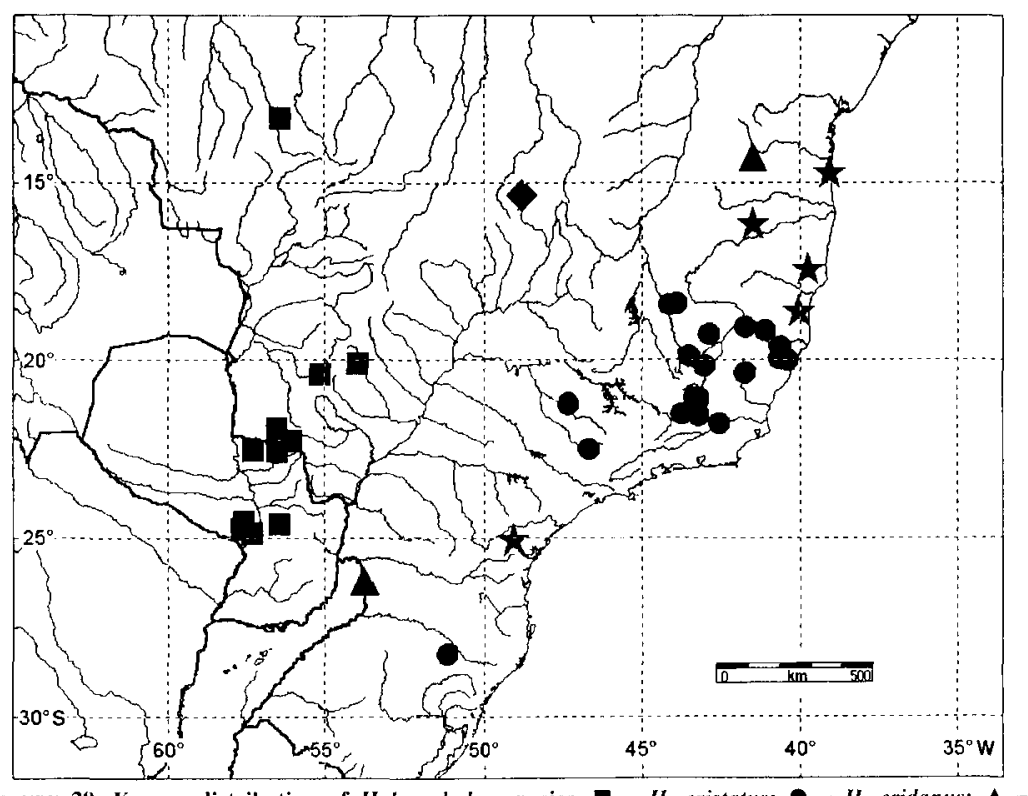

FIGURE 28. Known distribution of Holocephalus species.

$=H$. cristatus H. julieni; $\star=H$. sculptus; $\bullet=H$. simoni.

\section{Diagnosis}

The reduced eyes, trilobate cephalic process, and semicircular aspect of the elytra in lateral view will separate $H$. cristatus from all other species of Holocephalus.

\section{Description}

Male. Length $25.0-31.5 \mathrm{~mm}$. Width $17.0-20.5 \mathrm{~mm}$. Colour dark reddish-brown to black, surface glossy. Head. Dorsal surface strongly, transversely wrinkled to heavily punctate with large punctures in apical half, impunctate in basal half. Outer margin beaded. Clypeogenal suture distinct, slightly curved. Frons with tridentate horn; horn lon gitudinally elongated forming raised surface; lateral horns recurved in well-developed individuals, weakly recurved in others; medial horn apical, subequal to lateral horns; raised surface of armature heavily punctate, punctures large; basal edge of raised surface with medial inverted "U" depression. Eyes 2 times longer than wide, interocular width equals 10 transverse eye diameters (in dorsal view). Pronotum. Surface impunctate except impressed patch of dense, large punctures medially at apex, with line of punctures along basal margin. Pronotal margin anterior to pronotal swellings greatly thickened in medial half of apex. Disc with transverse swelling on anterior fourth of pronotum. Elytron. Surface glabrous. Pygidium. Width 2.5 times length medially. Surface glabrous, margin complete, slightly convex in lateral view. Apex with line of dense, medium-sized punctures along inside of margin. Venter. Propygidium width subequal to other abdominal segments, constricted medially. Legs. Protibia with 4 teeth; apical tooth subequal in size to adjacent tooth, projecting forward slightly; middie teeth projecting laterally; basal tooth subequal in size to apical tooth. Basal protibial tooth small in size, often worn and obsolete. Genitalia. Parameres symmetrical (Figs. 7-9) Ventral plate scleritized, asymmetrical, sigmate (Fig. 9).

Female. Length $23.0-31.3 \mathrm{~mm}$. Width $14.7-19.6 \mathrm{~mm}$. As in male, except in the following respects: Venter. Propygidium width approximately 2 times remaining abdominal segments, thickest medially.

\section{Distribution}

BRAZIL. Mato Grosso: Maracajú ( 1 †); Rancho Grande ( 1 ơ); Rosário ( 1 o*, + ); Vaçaria (1 ㅇ). PARAGUAY. Alto Paraguay: Primavera (1 o ). Amambay: Bella Vista $\left(1 \sigma^{*}\right)$. Caaguazú: Coronel Oviedo $\left(1 \sigma^{*}, 1 \%\right)$. Central: Asunción $\left(2 \sigma^{*} \sigma^{*}, 1 \%\right)$ Villeta (1 q). Cordillera: Emboscada (1 q). San Pedro: Cororó, Rio Ypané (1 q, $\left.1 \sigma^{\circ}\right)$ Yguarete Forest, Rio Verde, E. Santa Rosa $23.78^{\circ} \mathrm{S} 056.05^{\circ} \mathrm{W}$ ( 1 q). NO DATA. ( 1 i ).

\section{Temporal data}

January (2), February (1), June (1), November (6), December (4).

\section{Remarks}

This species seems to be restricted to the savanna (cerrado) of Brazil and Paraguay.

\section{Holocephalus sculptus (Gillet, 1907)}

(Figs. 10-12, 24, 28)

Atrichius sculptus Gillet 1907: 283

Holocephalus sculptus (Gillet): Gillet 1911: 58

Holocephalus sculptus (Gillet): Blackwelder 1944: 206.

\section{Material studied}

$60^{*} 0^{x}, 11 q q$ (BMNH, FZVC, ISNB, LACM, MNHN, MZSP, NMPC, SMFD, ZMHB)

Lectotype: Male (ISNB): "Coll. R. I. Sc. N. B. Brazil Bahia Collection E. CANDÈZE" (purple with two smaller labels glued on, typeface)/ "cf. Ann. Soc. Ent Belg. LI, 1907, p 283" (handwritten) / "see. Gillet. Col. Cat.: Junk, 1911, p 38 T. XIX, p 58 Holocephalus sculptus Gillet" (handwritten) / "TYPE" (pink with border, typeface) / "(Atrichius) = Holocephalus sculptus Gillet" (handwritten), "det. Gillet 1907 Atrichius sculptus n.sp. Gillet" (one smaller label glued on, typeface and handwritten) "ATRICHIUS SCULPTUS GILLET 1907 DET: SMITH \& GÉNIER 200 LECTOTYPE" (red, handwritten and typeface). Lectotype here designated. Statemen of taxonomic purpose: a lectotype is designated for $H$. sculptus in order to preserve the stability of nomenclature by selecting one specimen as the sole, name-bearing type of the taxon and as a reference standard for the taxon. Paralectotype: "Coll R. I. Sc. N. B. Brazil Bahia Coll. Candèze" (purple with one smaller label glued on, typeface and handwritten) / "TYPE" (pink with border, typeface) / "det. Gillet 1907 Atrichius sculptus Gillet." (one smaller label glued on, typeface and handwritten) / "ATRICHIUS SCULPTUS GILLET 1907 DET: SMITH \& GENIER 2001 PARALECTOTYPE" (yellow, handwritten and typeface). Gillet's (1907) original description was based on two specimens. The female specimen was erroneously identified as a male $(1 \%$ ISNB). 
The straight and slightly trilobate cephalic process, presence of coarse punctures on each side of the anterior pronotal bulge, and the pronotum with two separated tubercules on each side of the short, transverse carina will separate $H$. sculptus from all other species of Holocephalus.

\section{Description}

Male. Length 23.0-25.5 mm. Width 14.0-17.0 mm. Colour dark reddish-brown to black, glossy. Head. Dorsal surface strongly, transversely wrinkled to heavily punctate, punctures large. Apical margin beaded. Clypeogenal suture distinct, slightly curved. Frons with tridentate horn, horn with transverse carinae of uniform thickness with 2 lateral prominences, 1 medial prominence. Eyes 2 times longer than wide, interocular width equals 8.5 transverse eye diameters (in dorsal view). Pronotum. Surface impunctate except for impressed patch of dense, large punctures medioapically; densely punctate, medial impression present, posterior to pronotal swellings; dense band of punctures along inside of basal margin. Disc with 3 transverse swellings on anterior fourth; medial swelling transversely elongate, weakly bilobed; lateral swellings subequal in size to medial swelling, not elongated; swellings separated by 2 heavily punctate notches. Elytron. Surface glabrous. Pygidium. Width 2.0 times length medially. Surface glabrous, margin complete, slightly convex in lateral view. Venter. Propygidium width subequal to remaining abdominal segments, constricted medially. Legs. Protibia with 4 tecth; apical tooth subequal to adjacent tooth in size, projecting forward slightly; middle teeth projecting laterally; basal tooth subequal in size to apical tooth, small, often worn, obsolete. Genitalia. Parameres symmetrical (Figs. 10-12). Ventral plate scleritized, asymmetrical, sigmate (Fig. 12).

Female. Length $23.5-27.0 \mathrm{~mm}$. Width $14.0-17.5 \mathrm{~mm}$. As in male, except in the following respects: Venter. Propygidium width approximately 2 times remaining abdominal segments, thickest medially

\section{Distribution}

BRAZIL. Bahia: No locality $\left(3 \sigma^{\pi} \sigma^{\gamma} 1\right.$ \&); Una $\left(1 \sigma^{\pi}\right)$. Espírito Santo: Fazenda Klabin, 12 km E Pedro Canario, Municipio Conceição da Barra (1 o ); Reserva Florestal Companhia Vale do Rio Doce, Linhares (6 qq). Minas Gerais: Theophilo Ottoni (2 o + ). Santa Catarina: Blumenau $\left(1 \sigma^{*}\right)$. No locality: ( $\left.1 \sigma^{*}\right)$. NO DATA. ( 1 o $)$.

\section{Temporal data}

- January (3), October (1), December (2).

\section{Remarks}

The specimen from Blumenau (Santa Catarina) differs from the others in the shape of the cephalic carina, which is lacking a distinct, median sinuosity and acute lat eral teeth. The coarse pronotal punctures are also much reduced on each side of the median transverse bulge. The aedeagus does not show any important differences. At this time it is unclear to us if this variation represents the extreme of a cline or a distinct taxon. Until additional specimens from Santa Catarina and nearby regions are available for examination, the two populations are considered as one species. Holocephalus sculptus seems to be restricted to the Atlantic forest of Brazil.
(Figs. 2, 13-15, 25, 28)

Scarabaeus eridanus Olivier 1789: 133

Scarabaeus eridanus Olivier: Olivier 1790: 164

Copris (Holocephalus) eridanus (Olivier): Hope 1838: 323

Pinotus eridanus (Olivier): Harold 1869a: 125

Pinotus eridanus (Olivier): Harold 1869b: 61

Atrichius eridanus (Olivier): Gillet 1907: 283.

Holocephalus eridanus (Olivier): Gillet 1911: 58.

Holocephalus eridanus (Olivier): Lucas 1920: 330

Holocephalus eridanus (Olivier): Blackwelder 1944: 206.

Holocephalus eridantws (Olivier): Vulcano and Pereira 1967: 582.

\section{Material studied}

$158 \sigma^{\pi} \sigma^{*}, 117$ 우 (CASC, CMNC, CNCI, DEIC, ISNB, MCSN, MNHN, MZLU, MZSP, NMPC, SMFD, SMTD, USNM, ZMHB, ZMUC, ZSMC)

Lectotype: Male (MNHN): "COLLECTION OLIVIER TYPE" (green and round. typeface) / "SCARABAEUS ERIDANUS OLIVIER 1789 " LECTOTYPE A.B.T SMITH \& F. GENIER" (red, handwritten and typeface) / "Pinotus eridanus Oliv." (orange, handwritten) / "Copris Eridanus. Ol. Bras. G. Olivier." (handwritten) / "HOLOCEPHALUS ERIDANUS (OLIVIER) o Det:A.B.T.Smith 2001" (handwritten and typeface). Lectotype here designated. Statement of taxonomic purpose: lectotype is designated for $H$. eridanus in order to preserve the stability of nomenclature by selecting one specimen as the sole, name-bearing type of the taxon and as a reference standard for the taxon. Olivier (1789) did not indicate how many specimens were in the type series. The existence and location of paralectotypes is unknown.

\section{Diagnosis}

The high, bidentate cephalic process that is always narrower than half the head width will separate $H$. eridanus from all other species of Holocephalus.

\section{Description}

Male. Length 23.()-35.5 mm. Width 14.5-22.0 mm. Colour dark reddish-brown to black, glossy. Head. Dorsal surface strongly, transversely wrinkled in apical halt, smooth in basal half. Outer margin beaded, slightly upturned towards apex Clypeogenal suture distinct, weakly curved. Vertex with 2 slightly recurved horns, horns joined by transverse carinae. Eyes 2 times longer than wide, interocular width equals 10 transverse eye diameters (in dorsal view). Labrum with dense setae; setae long, reddish-brown. Pronotum. Surface impunctate except for impressed patch of dense, large punctures medioapically; densely punctate medial impression posterior to pronotal swellings; line of punctures along basal margin. Margin anterior to pronotal swellings greatly thickened in medial half of apex, inlaid with dense row of punctures. Dise with 2 transverse swellings anterior to medial impressions, swellings weakly projecting anteriorly on anterior fourth of pronotum. Elytron. Surface glabrous, strongly microsculptured. Pygidium. Width 2.6 times length medially. Surface glabrous, margin complete, surface slightly convex in lateral view. Venter. Propygidium width subequal to other abdominal segments, constricted medially. Legs. Protibia with 4 teeth; apical tooth subequal in size to adjacent tooth, projecting slightly forward; middle teeth projecting laterally; basal tooth subequal in size to apical tooth. Basal protibial tooth small. 
often worn and obsolete. Procoxae apically with dense patch of yellowish-brown setae. Genitalia. Parameres symmetrical (Figs. 13-15). Ventral plate scleritized, asymmetrical, subrhomboid (Fig. 9).

Female. Length 25.4-33.4 mm. Width 14.9-21.7 mm. As in male, except in the following respects: Venter. Propygidium width approximately 2 times remaining abdominal segments, thickest medially.

\section{Distribution}

ARGENTINA. Bueno Aires: Buenos Aires (erroneous locality label, $2 \sigma^{\circ} \sigma^{\circ}$ ) BOLIVIA. No data (erroneous locality label, $1 \sigma^{*}$ ). BRAZIL. Amazonas: Hanau (erroneous locality label, $1 \sigma^{*}$ ). Bahia: No locality (erroneous locality label, $50^{*} \sigma^{\pi}, 2$ o 9 ) Espirito Santo: No locality (18 $\left.\sigma^{\pi} \sigma^{*}, 129 \%\right)$; Cachoeira de Itapemirim (23 $\sigma^{*} \sigma^{*}, 16 \%$ )

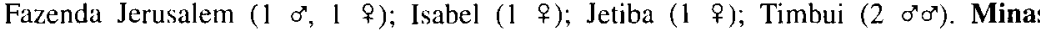
Gerais: No locality ( $2 \sigma^{*} \sigma^{*}, 2$ $q$ ); Serra do Caraça (1 $\sigma^{*}, 4$ $\%$ ); Lagoa Santa (1 $\left.q\right)$ Mar de Espanha (1 o); Matusinhos [= Matozhinos] (1 $\left.\sigma^{\prime}\right)$; Varzea [forest type] Alegre (2 $\sigma^{x} \sigma^{*}, 2$ \%q); Viçosa (1 +). Pernambuco: Pernambuco [= Recife ?] (1 $\left.\sigma^{*}\right)$. Rio de Janeiro: Corcovado [Pico de ?] ( $\left.1 \sigma^{\circ}\right)$; Floresta da Tijuca $\left(30^{\circ} \sigma^{\prime}\right)$; Mendes ( 1 o $)$; Nova

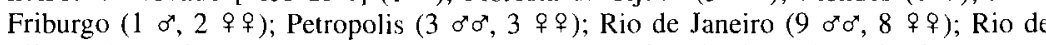
Tijuca (l $\left.\sigma^{\prime}\right)$; Santa Anna [de Itabapoana ?] (1 + ); Sto. [ = São] Antonio dos Brotos, Districto do San $\left[=\right.$ São] Fidelis $\left(1 \sigma^{\prime}\right)$. Rio Grande do Sul: San [= São] Leopoldo $\left.\sigma^{x} \sigma^{x}\right)$. São Paulo: Sumaré $\left(3 \sigma^{x} \sigma^{x}\right)$ : São Paulo $\left(1 \sigma^{x}\right)$. No data: $\left(54 \sigma^{x} \sigma^{x}, 24 q \%\right)$ FRENCH GUIANA. No locality (erroneous locality label, 1 q). PERU. No locality (erroneous locality label, $\left.1 \sigma^{*}\right)$. NO DATA. (18 $\left.\sigma^{\pi} \sigma^{*}, 23 q q\right)$.

\section{Temporal data}

January (1), February (7), March (2), April (1), October (1), November (3) December (2).

\section{Remarks}

The records from Bolivia, French Guiana, Peru, and Brazil (Amazonas and Bahia) are based on old specimens with dubious labels. These records are erroneous and not placed on the distribution map. The record from Buenos Aires is also erroneous and not cited in Martínez (1959). This species seems to be restricted to the various types of At lantic forest of eastern Brazil, from low to mid elevation (seal level to approximately $1000 \mathrm{~m})$

\section{Holocephalus simoni sp.nov.}

$$
\text { (Figs. 16-18, 26, 28) }
$$

\section{Material studied}

\section{3 o $^{\pi}$ (CMNC, CNCI, MNHN).}

Holotype: Male (CMNC): "LEOPOLDO BULHOES; Est. Goyaz; Nov.37; Dr.Nick" (typeface) / "H. \& A. HOWDEN COLLECTION ex. A. Martinez coll." (black border, typeface) / "HOLOCEPHALUS SIMONI SMITH \& GÉNIER HOLOTYPE" (red with black border, handwritten and typeface). Aedeagus and internal sac extracted. Paratypes: "Brazil" (handwritten) / "NO EDEAGUS ! Dét. F. Génier, 2000" (handwritten and typeface) "HOLOCEPHALUS SIMONI SMITH \& GENIER PARATYPE" (yellow, handwritten and typeface) $\left(1 \sigma^{*} \mathrm{CNCI}\right)$. "MUSEUM PARIS BRESIL Minas Geraes à Goyaz DE CASTELNAU 19-47" (typeface) / "19 47" (round label, green underneath, handwritten) / "Holocephalus Eridanus Ol. \& P. Lesne vid." (handwritten and typeface, erroneous determination and sex) / "HOLOCEPHALUS SIMONI SMITH \& GENIER PARATYPE" (yellow, handwritten and typeface) (1 $\sigma^{*}$ MNHN).

\section{Etymology}

This species is named in honour of the second author's son Simon.

\section{Diagnosis}

The wide and nearly straight pronotal process will separate $H$. simoni from all other species of Holocephalus (except $H$. julieni). The impunctate elytral striae on the apical declivity, shape of the parameres (Figs. 16-18), and habitat (cerrado) will separate this species from $H$. julieni.

\section{Holotype}

Male. Length $29.5 \mathrm{~mm}$. Width $18.0 \mathrm{~mm}$. Colour dark reddish-brown, glossy. Head. Dorsal surface strongly, transversely wrinkled to heavily punctate; punctures large. Outer margin beaded, slightly upturned towards apex. Clypeogenal suture distinct, curved. Frons with tridentate armature, consisting of transverse carinae of uniform thickness with 2 lateral prominences, 1 medial prominence. Eyes 2 times longer than wide, interocular width equals 9.0 transverse eye diameters (in dorsal view). Labrum with dense setae; setae long, reddish-brown. First segment of labial palpus greatly enlarged, flattened into lobes; each lobe subequal in length to labrum; second segment enlarged, flattened, less than one-third first segment length. First and second segments of labial palpus with dense setae; setae long, reddish-brown. Third segment of labial palpus not enlarged or flattened, without setae. Second and third labial palpus segments hidden by first segment of labial palpus in ventral view. Antenna 9-segmented; second segment elongated, subequal to length of segments 3-7; antennal club reduced, twice width of antennal segment 7. Pronotum. Surface glabrous except for impressed patch of dense, large punctures medioapically; densely punctate medial impression posterior to pronotal swellings, with row of punctures along inside of basal margin. Pronotal margin anterior to pronotal swellings greatly thickened in medial half of apex. Disc with transverse swelling on anterior fourth. Elytron. Surface glabrous, impunctate between striae; striae impressed, moderately punctate. Elytron with 9 striae; striae $1-6$ impressed, punctate, extending to base; stria 7 impressed, punctate, terminating before base. Striae 8 and 9 basomedially obscured by lateral margin, apically distinct, divergent. Pygidium. Width 2.0 times length medially. Surface glabrous, margin complete, surface slightly convex in lateral view. Venter. Propygidium width subequal to remaining abdominal segments, constricted medially. Legs. Protibia with 4 teeth; apical tooth subequal to adjacent tooth in size, projecting forward slightly; middle teeth projecting laterally; basal tooth subequal to apical tooth in size, worn, obsolete. Protibia inner and outer surface with thin, longitudinal line of dense yellowish-brown setae. Forecoxa apically with dense patch of yellowish-brown setae. Genitalia. Parameres symmetrical (Figs. 16-18). Ventral plate scleritized, asymmetrical, suboval (Fig. 18).

\section{Variation (2 paratypes)}

Length 25.5-29.5 mm; greatest width $16.0-18.0 \mathrm{~mm}$. Colour dark reddish-brown to black. Female unknown. 


\section{Temporal data}

November ( 1 )

\section{Holocephalus julieni sp.nov.}

(Figs. 19-21, 27, 28)

\section{Material studied}

$30^{\pi} \sigma^{\pi}, 1$ i (CMNC, MNHN, MZSP).

Holotype: Malc (MZSP): "BRASIL: Minas Gerais Aguas Vermelhas XII-1997 Bello \& Vaz-de-Mello" (typeface) / "HOLOCEPHALUS JULIENI SMITH \& GÉNIER HOLOTYPE" (red with border, handwritten and typeface). Aedeagus and internal sac extracted. Allotype: Female (CMNC): "BRASIL: Rio Grande do Sul Santo Augusto I- 1969 Roppa" / "H. \& A. HOWDEN COLLECTION ex. A. Martinez coll." (typeface) $/$ "HOLOCEPHALUS JULIENI SMITH \& GÉNIER ALLOTYPE" (red with border handwritten and typeface). Paratypes: "BRÉSIL BAHIA COLL. V. DE POLL" (black border, typeface) / "MUSÉUM PARIS 1928 COLL. A. BOUCOMONT" (green, typeface) / "HOLOCEPHALUS JULIENI SMITH \& GÉNIER PARATYPE" (yellow, handwritten and typeface) $\left(1 \sigma^{\prime} \mathrm{CMNC}\right)\left(1 \sigma^{\prime} \mathrm{MNHN}\right)$.

\section{Etymology}

This species is named in honour of the second author's son Julien.

\section{Diagnosis}

The wide and nearly straight pronotal process will separate $H$. julieni from all other species of Holocephalus, except $H$. simoni. The punctate elytral striae on the apical declivity, shape of the parameres (Figs. 19-21), and habitat (Atlantic forest) will separate this species from $H$. simoni.

\section{Holotype}

Male. Length $27.0 \mathrm{~mm}$. Width $18.5 \mathrm{~mm}$. Colour black, glossy. Head. Dorsal surface strongly, transversely wrinkled in apical half and strongly punctate with large punctures in basal half. Outer margin beaded, slightly thickened apically. Clypeogenal suture distinct, curved. Frons with tridentate armature, consisting of transverse carina of uniform thickness with 2 weak, lateral prominences, 1 weak medial prominence. Eye 2 times longer than wide, interocular width equals 9 transverse eye diameters (in dorsal view). Labrum with dense setae; setae long, reddish-brown. First segment of labial palpus greatly enlarged, flattened into lobe; second segment enlarged; flattened, less than orte-third length of first segment. First and second segments of labial palpus with dense setae; setae long, reddish-brown. Third segment of labial palpus not enlarged or flattened, without setae. Second and third labial palpus segments hidden by first segment in ventral view. Antenna 9-segmented, second segment elongated, subequal to length of segments 3-7; antennal club reduced, twice width of antennal segment 7 . Pronotum. Surface impunctate except for impressed patch of dense, large punctures medioapically, with densely punctate medial impression posterior to pronotal swellings and row of punctures along inside of basal margin. Pronotal margin anterior to pronotal swellings thickened in medial half of apex. Disc with transverse swelling on anterior fourth Elytron. Surface glabrous, impunctate between elytral striae; elytral striae impressed moderately punctate. Each elyton with 9 striae; striae 1-6 impressed, punctate, extending to base; stria 7 impressed, punctate, terminating before base. Striae 8 and 9 basomedially obscured by lateral margin, apically distict, divergent. Pygidium. Width 20 times length medially. Surface glabrous; margin complete, slightly convex surface in lateral view. Venter. Propygidium width subequal to remaining abdominal segments, constricted medially. Legs. Protibia with 4 teeth; apical tooth slightly subequal to adjacent tooth in size, projecting forward slightly; middle teeth projecting laterally; basal tooth small. Protibia inner and outer surface with thin, longitudinal line of dense, yellowish-brown setae. Procoxae with dense patch of yellowish-brown setae on apical side. Genitalia. Parameres symmetrical (Figs, 19-21). Ventral plate scleritized, asymmetrical, subrhomoid with lateral hook (Fig. 21)

\section{Variation (1 allotype, 2 paratypes)}

Length $24.5-27.0 \mathrm{~mm}$; greatest width $14.5-18.5 \mathrm{~mm}$. Female propygidium width approximately 2 times remaining abdominal segments, thickest medially.

\section{Temporal data}

January (1), December (1)

\section{Acknowledgements}

We thank the individuals and institutions mentioned in the "Specimens" section for making material available to us for study. Brett Ratcliffe (University of Nebraska) is acknowledged for his critical review of the manuscript. We also thank Fernando Vaz-de-Mello (Universidade Federal de Viçosa, Brazil) for many insightful observations of Holocephalus. This project was supported, in part, by National Science Foundation/Partnerships for Enhancing Expertise in Taxonomy grant (DEB-9712447) to B Ratcliffe and M Jameson (University of Nebraska).

\section{References}

Blackwelder RE 1944. Checklist of the coleopterous insects of Mexico, Central Americin, the West Indies and South America Part 2 United States National Museum Bulletin 185: 189-341

an F 1996. A revision of the Neoropical genus Ontherus. Frichson (Coleoptera: Scaratbaeidac. Scarabacinae). Memoirs of the Entomological Society of Cantada 170: $1-165$

Giller JJ-E. 1907. Genre nouveau et espèces nouvelles du groupe des Pinotinae. Annales de la Societe Entomologique de Belgique 51: 282-4

Gillet JJ-E. 1911. Scarabaeidae: Coprinae I. Coleopterorum Catalogus 38: 1-263

Harold E. 1869a. Scarabaeidae. pp 979-1346 in M Gemminger, E Hurold (Eds), Catalogus Coleopterorum hucusque descriptorum synonymicus et systematicas. Volume 4. EH Gummi. Monachii

Harold E. 1869b. Abünderungen vergebener Namen. Coleopterologische Hefte 5: 122-5

Hope FW. 1838. Observations on the lamellicorns of Olivier. The Entomological Magazine 5: 312-26

Lucas R. 1920. Catalogus alphabeticus generum et subgenerum Coleopterorum orhis terrarum torius. Part 1 Berlin: R Sticker

Martínez. A. 1959. Catálogo de los Scarabaeidae argentinos (Coleoptera). Revista del Museo Argentino de Ciencias Naturales "Bernardino Rivadavia" 5: 1-130

Montreuil O. 1998. Analyse phylogénétique el paraphylie des Coprini et Dichotomini (Coleoptera: Scarabaeidae). Scénario biogéographique. Amnales de la Seciete Entomologique de France 34: 135-48

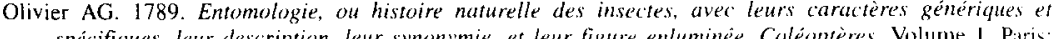
Baudoin

Olivier AG. 1790. Encomologie, ou histoire naturelle des insectes, avec leurs caractères génériques et spécifiques, leur description, leur synonymie, et leur figure enluminée. Coléoptères. Volume 2. Paris: Baudoin 
Vaz-de-Mello FZ. Louzada JNC. Schoereder JH. 1998. New data and comments on Scarabaeidae (Coleoptera; Scarabacoidea) associated with Attini (Hymenoptera: Formicidae), The Coleopterists Bulletin 52: 209-16

Vulcano MA. Pereira FS. 1967. Sinópse dos Passalidae e Scarabaeidae s. str. Da região Amazônica (Insecta, Coleoptera). Atas do Simposio sobre a Biota Amazonica 5: 533-603

(Received: 26 March 2001; accepted: 24 August 2001) 